\title{
Empatia e conflito entre o trágico e o cômico: uma leitura de Comédia em tom menor, de Hans Keilson
}

[Empathy and conflict between tragedy and comedy: reading Komödie in Moll, by Hans Keilson]

http://dx.doi.org/10.11606/1982-88372341176

\section{Patricia Helena Baialuna de Andrade ${ }^{1}$}

\begin{abstract}
Hans Keilson is one of the numerous German-speaking writers who published works about World War II and tangent themes between the 1930s and 1950s. Recognized only later, Keilson wrote an autobiography, novels, and essays in which his experiences, fiction, and his technical knowledge as a psychoanalyst are all present. In this article we interpret the novel Komödie in Moll, regarding empathy as a fundamental key for reading the work, focalization as a narrative resource to reach empathy, and analyzing the presence of comic elements involved in the serious and sometimes tragic reality that is built in the short story.
\end{abstract}

Keywords: Hans Keilson; Perspective; Empathy; Comedy.

Resumo: Hans Keilson faz parte do numeroso grupo de escritores de língua alemã que publicou entre as décadas de 1930 e 1950 obras sobre a Segunda Guerra Mundial e temas tangentes. Reconhecido tardiamente, Keilson escreveu romances, autobiografia e ensaios em que se confundem suas experiências, seu conhecimento técnico como psicanalista e a ficção. Neste artigo propomos uma leitura da novela Comédia em tom menor (Komödie in Moll), destacando a empatia como chave fundamental para leitura da obra, a focalização como expediente narrativo para alcançá-la, e a presença de elementos cômicos imiscuídos à realidade grave e por vezes trágica que é construída no conto.

Palavras-Chave: Hans Keilson; Perspectiva; Empatia; Cômico.

\section{Introdução}

Durante as décadas posteriores ao fim do regime nacional-socialista, a Alemanha e vários países vizinhos assistiram, acompanhando a libertação do domínio nazista, à publicação de inúmeras obras retratando a experiência da perseguição política ou étnica, dos campos

\footnotetext{
${ }^{1}$ Department of Spanish and Portuguese, Brigham Young University, 3145 JFS Building, BYU, Provo, Utah, 84602-0002, Estados Unidos. E-mail: patriciabaialuna@ gmail.com. ORCID: 0000-0002-8985-1068

(cc) BY-NC
} 
ANDRADE, P.H.B. - Empatia e conflito entre o trágico e o cômico

de concentração, da resistência e tantas outras questões relacionadas a este período crítico da história europeia. Nesta época tornaram-se famosos os poemas de Paul Celan e Günter Eich, os romances de Alfred Andersch, Günther Grass, entre muitos outros. Entretanto, nem todos que escreveram obras de alto valor literário - e até mesmo histórico - sobre o período da Segunda Guerra foram rapidamente reconhecidos. É o caso de Hans Keilson, autor alemão de origem judia, psiquiatra e ensaísta, cujo reconhecimento enquanto escritor só foi tributado décadas depois de suas principais publicações. Se há hoje na Alemanha vários pesquisadores ${ }^{2}$ ocupando-se de analisar e lançar luz à obra do autor, a academia brasileira ainda não lhe deu o merecido espaço.

Nascido em 1909 em Bad Freienwalde, Hans Keilson foi médico psiquiatra e psicanalista, professor de ginástica em sua juventude (devido às sanções do governo nacional-socialista a estudantes de medicina judeus) e romancista. Autor de reconhecidos ensaios sobre psiquiatria - como Sequentielle Traumatisierung bei Kindern: Untersuchung zum Schicksal jüdischer Kriegswaisen [Traumatização sequencial em crianças: pesquisa sobre órfãos de guerra judeus], em que analisa os efeitos e instauração do trauma em crianças sobreviventes ao Holocausto - o próprio Keilson declarou não ver diferença entre seus textos literários e seu trabalho científico (apud NIEKERK 2013). Muitas são as convergências, como o próprio romancista menciona, entre sua vivência, suas análises clínicas e seus textos literários; deste modo, são abundantes os elementos autobiográficos em sua escrita ficcional. É o que se pode notar no romance que propomos neste artigo analisar, Comédia em tom menor (Komödie in Moll), e também no romance Der Tod des Widersachers (A morte do inimigo) ${ }^{3}$ e no romance autobiográfico Das Leben geht weiter (A vida continua, ainda sem tradução para o português publicada).

Enquanto Das Leben geht weiter traz numerosos elementos da autobiografia do autor e é, segundo sua própria declaração, relato de experiências próprias (ainda que ficcionalizadas), A morte do inimigo é narrada em primeira pessoa e lida por parte da crítica como romance psicológico (WEYMANN 2013: 88). Comédia em tom menor destaca-se das duas obras mencionadas, em princípio, pela narrativa em terceira pessoa e pela maior distinção entre o personagem Nico e o próprio Keilson; seria, portanto, dentre os três títulos mencionados, o que mais facilmente se poderia definir como obra ficcional - e ainda assim não está livre de convergências com fatos da biografia do autor. Embora

\footnotetext{
${ }^{2}$ Cf. Braese (2010); Schröder, Weymann, Widmann (2013).

${ }^{3}$ Cf. Andrade (2019). 
ANDRADE, P.H.B. - Empatia e conflito entre o trágico e o cômico

a narrativa em terceira pessoa não possua, em princípio, a mesma aproximação da subjetividade do narrador como aquela em primeira pessoa, procuraremos adiante apontar para os expedientes narrativos - especialmente aqueles relacionados à focalização - que suscitam a empatia do leitor à leitura, e destacar os elementos cômicos do conto.

A presença do cômico nos textos poderia, em um primeiro momento, apontar para um distanciamento entre o leitor e as personagens / a história narrada, o que pareceria contradizer a aproximação trazida por uma leitura empática da obra. Entretanto, procuraremos discutir e subsidiar, através da "teoria do humor enquanto criptografia" (FLAMSON; BARRETT 2008) que o riso pressupõe o compartilhamento de conhecimentos, atitudes e preferências entre aquele que produz o humor e seu receptor. Deste modo, ao apontarmos para os elementos que trazem comicidade a certas passagens de Comédia em tom menor, reforçaremos a tese da empatia como chave para leitura do conto.

\section{cômico em meio à tragédia (histórica)}

Comédia em tom menor é a narrativa de um jovem casal holandês que decide dar abrigo em sua casa a um judeu que fugia da perseguição nazista na Holanda dominada do início da década de 1940. Wim e Marie, acostumados a uma pacata e sistemática vida como contador em uma fábrica e dona de casa, veem sua rotina alterada pela corajosa decisão de dar guarida em seu lar a um desconhecido. Com a chegada de Nico, passam a experimentar sensação de insegurança constante, temendo que a presença do refugiado pudesse ser descoberta e denunciada por um vizinho, por um vendedor, pela faxineira ou qualquer outro que se aproximasse de seu lar.

Estabelecida uma rotina e várias medidas de segurança, o tempo passa não sem alguns sobressaltos - como os episódios do peixeiro e da faxineira, que serão comentados adiante - até que Nico adoece e morre aproximadamente um ano após sua chegada. $\mathrm{O}$ médico Dr. Nelis, ciente e conivente com a ocultação do homem - e, subentende-se, com muitos outros casos parecidos - ajuda Wim a carregar o cadáver até um parque vizinho, na escuridão da noite. O problema - que é tema dos primeiros capítulos do romance parecia tristemente resolvido, quando Marie dá-se conta de que o corpo estava vestido com um pijama de Wim, e este trazia na etiqueta a identificação do dono que era praxe da lavanderia. Temendo serem identificados pela polícia e terem que arcar com graves consequências por proteger um fugitivo, o casal é que deixa o lar para esconder-se em 
ANDRADE, P.H.B. - Empatia e conflito entre o trágico e o cômico

uma modesta pensão em cidade vizinha, aguardando que parentes os ajudassem a se livrar de problemas com as autoridades, mas não livres de experimentar a mesma amarga sensação vivida por Nico, enclausurado, temendo ser descoberto e sem previsão de liberdade.

Depois de alguns dias, que para o casal pareceram intermináveis pelo desconforto da situação, Coba, a irmã de Wim, consegue estabelecer os contatos necessários para assegurar que o irmão e a cunhada não sofreriam qualquer consequência pelo acolhimento ao refugiado. De volta a sua casa, Marie retoma sua rotina doméstica e Wim prossegue com os estudos para uma prova que poderia lhe garantir promoção na carreira; isto é, a vida segue como se não houvessem vivenciado o triste fim da vida de Nico.

Carl Niekerk (2013: 116) atribui ao conto função documental e afirma pertencer à memória coletiva dos holandeses nos anos 1950. De fato, tornou-se depois da guerra conhecido que muitos cidadãos tiveram a coragem e o altruísmo de esconder judeus em cômodos, sótãos e porões de suas casas, como descreve em seu diário Anne Frank, a mais célebre das vítimas do nazismo a vivenciar tal experiência. Faz-se oportuno mencionar que Hans Keilson também encontrou abrigo na casa de um jovem casal holandês na cidade de Delft, quando se viu forçado a deixar a Alemanha. Lá engajou-se em atividades de resistência, auxiliando outros fugitivos com documentos falsificados e outros meios de auxílio. Na dedicatória de Comédia em tom menor lemos "Para Leo e Suus, em Delft", sugerindo que a obra trará referências à experiência de Keilson. No entanto, o texto frustra tal expectativa, e a única referência direta à biografia do autor é essa dedicatória. Keilson comentou, entretanto, em seu ensaio In der Fremde zuhause:

Em meu esconderijo escrevi um poema longo, de versos brancos, com o título "A uma sonhadora", e a novela Comédia em tom menor, a história de um clandestino. O centro desta narrativa é uma anedota, uma história verdadeira. Eu a ouvi em Delft, onde estava escondido. Ele lida com a morte - natural resultante de pneumonia de um judeu oculto em seu esconderijo (apud WIDMANN 2013:55-56). ${ }^{4}$

\footnotetext{
${ }^{4}$ „In meinem Versteck schrieb ich ein langes Gedicht, „,vers blancs“, mit dem Titel Einer Träumenden [...] und die Novelle Komödie in Moll, die Geschichte eines Untergetauchten [...]. Der Kern dieser Erzählung ist eine Anekdote, eine wahre Begebenheit. Ich vernahm sie in Delft, wo ich untergetaucht war. Sie handelt vom - normalen - Tod infolge einer Lungenentzündung eines jüdischen Untergetauchten in seinem Versteck“. Traduções do inglês e do alemão feitas pela autora.
} 
ANDRADE, P.H.B. - Empatia e conflito entre o trágico e o cômico

$\mathrm{O}$ argumento central do conto, portanto, seria curiosamente um acontecimento real que o autor chama de anedota. Cabe aqui um comentário relativo ao título do conto: fazse perceptível ao leitor que não se trata de uma comédia no sentido lato, como história que faz rir. Pelo contrário, os acontecimentos narrados são, na maior parte, dramáticos e graves até ao menos empático leitor. Contudo, vários elementos cômicos podem ser identificados no conto; um dos principais é a inversão de papéis por que passam Wim e Marie. Se davam abrigo a Nico, passam então a fugitivos que - pelo menos segundo seus receios - a qualquer momento podem ser encontrados pela polícia e levados à prisão.

Outro elemento cômico é a necessidade do casal se livrar de um corpo, o que faz não sem certa dificuldade, assumindo a imprevista função de ocultadores de um cadáver sem serem assassinos. A própria morte natural de Nico, que por tanto tempo estivera escondido pela ameaça de ser assassinado, é de grande ironia e, portanto, pertinente ao cômico. Ainda, e não menos importante, é o final da história: ao invés de ser trágico, restabelece a ordem e a rotina do casal Wenders.

Andreas M. Widmann (2013), ao analisar o conto, cita o ensaio Theaterprobleme [Problemas do teatro], escrito em 1954 por Friedrich Dürrenmatt, em que o autor postula serem os acontecimentos catastróficos do século XX melhor representados pela comédia, dentro de uma estética do grotesco e do absurdo (WIDMANN 2013: 69), em que o acaso pode ter efeito relevante. É o que faz Keilson em Comédia em tom menor: traz para a escrita ficcional acontecimentos contundentemente reais - que ele próprio e outros conhecidos seus vivenciaram - em forma de ficção, acrescentando a ironia e o elemento cômico para representar uma realidade tragicamente absurda. Dürrenmatt afirma, no mesmo ensaio, que "o trágico ainda é possível, mesmo que a tragédia pura não o seja. Podemos obter o trágico a partir da comédia como um momento aterrador, ou como um abismo que se abre" (DüRRENMATT 1955: 32) . O cômico poderia ser, para o autor, “expressão do desespero" (idem: 32$)^{6}$.

A realidade desesperadora se encontra entremeada à narrativa mesmo que em detalhes: enquanto o casal e Nico jantam e fingem normalidade em uma conversa trivial, ouvem-se ao longe os aviões bombardeiros ingleses. O mesmo som acompanha Wim e o

\footnotetext{
${ }^{5}$ „Doch ist das Tragische immer noch möglich, auch wenn die reine Tragödie nicht mehr möglich ist. Wir können das Tragische aus der Komödie heraus erzielen, hervorbringen als einen schrecklichen Moment, als einen sich öffnenden Abgrund [...]“.

${ }^{6},[\ldots .$.$] die Komödie sei der Ausdruck der Verzweiflung [...]“$

Pandaemonium, São Paulo, v. 23, n. 41, set.-dez. 2020, p. 176-190
} 
ANDRADE, P.H.B. - Empatia e conflito entre o trágico e o cômico

Doutor Nelis ao prepararem o corpo de Nico antes de levá-lo para o parque. Os arranjos domésticos mais triviais, como a compra do leite e a leitura do jornal, revezam-se à inquietante presença desses ruídos de destruição e guerra. Podemos associar a constante presença desse som amedrontador ao título do conto: Moll, enquanto gênero tonal na música, é considerado de melodia triste e melancólica. O título do conto, portanto, bem descreve a coexistência, na história, de um desenvolvimento por vezes cômico e irônico com a triste lembrança permanente da verdade histórica de tais absurdos.

Além dessa configuração de um ambiente de medo através do som de fundo, a rotina da casa é por vezes atrapalhada por um ameaçador imprevisto; comentaremos duas dessas passagens que Widmann (2013) associa às pantomimas por conterem "trapalhadas" de uma personagem e ausência de diálogos ${ }^{7}$; discordamos, porém, que tais passagens sejam de definitivo caráter cômico pelo forte desconforto que prevalece após cada cena.

Na primeira ocasião, Nico descera solicitamente à cozinha atraído pelo cheiro de leite queimado. Lá encontra Marie atenta ao incidente, mas no mesmo instante chega o peixeiro, cujo hábito era entrar para limpar o peixe na cozinha. Encurralado, Nico não sabe por onde fugir para não ser visto, e Marie o esconde no pequeno banheiro do corredor durante a meia hora que o peixeiro levou para fazer seu trabalho, ser pago e sair. Se a urgente necessidade de se esconder no banheiro poderia parecer pantomímica (pela ausência de falas e enfática descrição dos gestos e expressões), a cena perde a comicidade com o diálogo entre Wim, Marie e Nico mais tarde, durante o jantar.

"Da próxima vez eu deixo estar -“, disparou ele de repente, arrematando o tamborilar com uma leve pancada na mesa, "-simplesmente fico lá em cima e deixo o leite queimar."

"E eu vou me esforçar", retrucou Marie, em tom de sarcasmo, olhando com interesse para o quadro acima da estufa, como se o estivesse vendo pela primeira vez, "para apagar o fogo na hora certa."

Silêncio. Silêncio constrangedor. Na hora, Nico se arrependeu pela pancadinha na mesa. Porém, continuou como que preso à cadeira, olhando um e outro em busca de socorro. (KEILSON 2011: 50-51)

Um dos elementos que poderiam ser considerados cômicos dentro da história, portanto, converte-se em desconforto e constrangimento de todos, especialmente de Nico,

\footnotetext{
${ }^{7}$,Die Passage, in der kein Wort gesprochen wird, lässt sich als pantomimischer Ablauf lesen, wobei der Erzähler über dem Geschehen steht und die in Bewegungen, Gesichtsregungen und Körperreaktionen gespiegelten Emotionen und Absichten der beiden Akteure erläutert" (WIDMANN 2013: 60).
}

Pandaemonium, São Paulo, v. 23, n. 41, set.-dez. 2020, p. 176-190 
ANDRADE, P.H.B. - Empatia e conflito entre o trágico e o cômico

percebendo-se culpado pelo próprio apuro e por colocar o casal sob o risco de serem denunciados pelo peixeiro.

A outra passagem de traço pantomímico trata de um encontro acidental com a faxineira, já que Nico sempre ficava em silêncio no quarto nas tardes em que a mulher lá estava. Próximo do horário em que Marie costumava trazer-lhe chá, Nico ouviu passos na escada e entreabriu a porta para pegar a xícara, mas seus olhos encontraram os olhos da estranha mulher.

Nico levou o indicador da mão direita aos lábios, balançou vagarosamente o rosto contraído e triste e fechou a porta com delicadeza.

A mulher entrou no quarto contíguo e lá deixou o saco de roupa. Quando ela voltou a descer a escada, Nico estava deitado na cama, molhado de suor, como que paralisado, o rosto coberto com as mãos. Já não sabia se era verdade ou alucinação. Doía-lhe a cabeça. (KEILSON 2011: 54)

Enquanto Widmann (2013: 60) considera que tal passagem pode ser lida como pantomímica pela ausência de falas e desenvolvimento da cena por meio de gestos corporais e expressões faciais, o que permanece após a leitura da cena é a angústia de Nico e a lembrança de sua triste situação, vendo-se ameaçado aos menores lances cotidianos.

Consideramos, desse modo, que o elemento cômico do conto - evidente na ironia da inversão de papéis e em vários outros elementos já comentados, como as cenas pantomímicas - rivaliza com o trágico pela gravidade e sofrimento das personagens em cada cena destacada. De fato, o relato das cenas é feito de forma a sugerir comicidade através desses elementos mencionados - a ironia, a pantomima, gestos atabalhoados. $\mathrm{O}$ leitor é convidado, portanto, a ler a história de Wim, Marie e Nico com a cumplicidade e relativa leveza, ainda que momentânea - de uma peça cômica. Contudo, não tarda para ser lembrado da realidade lamentável e grotesca que conduz àqueles acontecimentos.

Concluímos tal argumentação com uma cena-chave na narrativa, aquela em que se opera a passagem de Wim e Marie para o papel de fugitivos, no diálogo de Marie com a cunhada, Coba:

"Como ele estava vestido?", perguntou Coba, pegando uma pilha grande de camisas bem passadas que pertenciam a Wim.

"De pijama - um pijama de Wim", acrescentou Marie, pegando a pilha das mãos de Coba em direção ao armário.

"Bom" - Coba tornou a se curvar e tirou do fundo do saco o monte de toalhas de rosto que restavam. Estavam todas marcadas. 
“...Nesse caso, só espero que você não tenha se esquecido de retirar o número de registro na tinturaria." Voltou a endireitar o corpo e ficou esperando Marie, que ainda estava ocupada no armário.

"Oh, Coba -", disse quase sem voz, como se estivesse caindo dentro do armário. Virouse, e Coba viu dois olhos arregalados e inundados de um pavor que crescia a cada segundo, a ponto de transbordar das pálpebras e escorrer pelo rosto e pelos braços e lhe tomar o corpo (KEILSON 2011: 97).

É relevante notar que, no rico escopo das obras literárias produzidas após o fim da Segunda Guerra em países fortemente afetados pela catástrofe, a maior parte delas traz relatos de experiências (reais ou ficcionais) relacionadas ao exílio, à perseguição política, ao antissemitismo e mesmo à experiência nos campos de concentração, sendo predominante um tom grave de denúncia, revolta e indignação diante de tais fatos históricos. Hans Keilson, por sua vez, retrata tais experiências com a peculiaridade de mesclar um assunto extremamente grave a uma forma eivada de passagens potencialmente cômicas. Reiteramos, desse modo, a pertinência do título escolhido para seu conto.

Ao observarmos na obra os elementos geradores de humor próprios da comédia, que procuramos pouco acima descrever, podemos questionar o aspecto ético de tal estruturação, uma vez que o cômico se dá, lato sensu, mediante um distanciamento entre o leitor e o personagem que permite ao primeiro rir diante das peripécias do segundo. Bergson (2004: 100) descreve tal distanciamento: "quando a pessoa do próximo deixa de nos comover, só ai pode começar a comédia”. O leitor do romance de Keilson poderia, então, questionar a ética de se criar humor a partir de acontecimentos históricos tão graves. Flamson e Barrett (2008: 264), entretanto, defendem que a decodificação do humor depende de conhecimentos ou disposições em comum entre aquele que produz e aquele que recebe (no caso da obra literária, aquele que lê) uma anedota:

No caso do humor, a "chave" é o conhecimento necessário para produzir e entender a anedota. [...] Em uma piada de sucesso, tanto o produtor quanto o receptor compartilham o conhecimento comum de fundo - a chave - e a piada é projetada de tal maneira (incluindo dispositivos como a incongruência) que há um ajuste não aleatório entre aquilo que se diz superficialmente e esse conhecimento de base que seria aparente apenas para outra pessoa com o mesmo conhecimento prévio. O humor, portanto, garante ou torna altamente provável que o conhecimento oculto e específico seja necessário para produzir a expressão humorística, e que o mesmo conhecimento esteja presente em qualquer um que entenda o humor (FLAMSON; BARRETT 2008: 264). ${ }^{8}$

\footnotetext{
8 "In the case of humor, the "key" is the background knowledge needed both to produce and to understand the joke. [...] In a successful joke, both the producer and the receiver share common background knowledge - the key - and the joke is engineered in such a way (including devices like incongruity) that there is a 
Através dos excertos de Comédia em tom menor acima mencionados, percebemos que o cômico de cada passagem se dissolve com a impressão de tristeza e desconforto que prevalece ao final de cada trecho. Tal percepção evoca no leitor o reconhecimento da gravidade de tal contexto histórico e social, em que tantas pessoas se viram em situação semelhante à de Nico, e é fundamental para o estabelecimento de empatia, pois "o riso é incompativel com a emoção" (BERGSON 2004: 104). Se a obra de Keilson não é, à primeira vista, engajada em expor os horrores do nazismo, percebemos que seu posicionamento ético se dá, particularmente e em um primeiro momento, através do cômico, um elemento estético poucas vezes explorado com esse fim por autores contemporâneos e conterrâneos seus.

Além dessa aproximação pelo conhecimento em comum, há várias indicações no texto que sugerem a importância da empatia para a leitura do conto, como procuraremos demonstrar a partir deste ponto.

\section{Empatia narrativa}

Partimos da observação da estrutura do conto: dividido em doze capítulos, reitera no início dos dois primeiros a cena em que o médico auxilia Wim nos preparativos para se livrarem do cadáver de Nico, tendo por pano de fundo o ruído dos aviões de guerra. A história já parte, portanto, da morte do judeu, e a partir daí as memórias e falas das personagens revelam a rotina do casal, como tomaram a decisão de abrigar Nico, e a tensão por sua morte imprevista. A partir do capítulo 3, a ordem da narrativa torna-se mais linear, descrevendo a rotina do casal antes da chegada do hóspede, as adaptações e medidas de segurança que adotaram para recebê-lo, seu convívio, as conversas da hora do jantar, os pequenos incidentes diários, o adoecimento do homem e sua morte. Até o décimo capítulo, a focalização se dá em Wim e Marie, com quase todos os pensamentos revelados pelo narrador onisciente pertencendo a um dos dois. Outro termo com uso semelhante à focalização de Genette (1995) é perspectiva ou ponto de vista (este último

\footnotetext{
nonrandom fit between the surface utterance and this background knowledge that would only be apparent to another person with the background knowledge. Humor therefore guarantees or makes highly likely that specific, hidden knowledge was necessary to produce the humorous utterance, and that the same knowledge is present in anyone who understands the humor".
} 
mais comum na academia americana). Para Niederhoff (2019: s/p), por exemplo, "[...] O modo de representação da história é influenciado pela posição, personalidade e valores do narrador, das personagens e, possivelmente, outras entidades hipotéticas no mundo da história"9. Ao apresentar a história de Nico pela perspectiva do casal que o ocultou, o narrador torna mais próxima do leitor a realidade dos muitos holandeses que, de forma semelhante, arriscaram-se em atos altruístas durante a invasão nazista. Essa perspectiva é a que prevalece na maior parte do conto, mas não é única. Alternando-se entre os pontos de vista de Wim e Marie, há ainda trechos em que a posição de Nico é posta em destaque; portanto, a focalização (ou perspectiva, como trataremos) é interna e variável - ou múltipla.

Se a perspectiva pode ser entendida como seleção ou restrição de informações narrativas em relação à experiência e conhecimento do narrador e/ou das personagens (NIEDERHOFF 2019), pode-se considerar que a narrativa privilegia a perspectiva do personagem judeu em passagens como a seguinte:

Quando respirava fundo, sentia cheiro de gás. Gás! O quarto estava cheio de gás. Fechava os olhos e mergulhava a cabeça no travesseiro. O que os outros sabiam daquilo? E, se soubessem - que significado teria para eles? Em seu lar protegido, seguro. Protegido? Seguro? Depois de o terem acolhido? Não, não, que injustiça. Mas a casa deles, a sala de estar, suas coisas - o mundo deles, como tudo aquilo o atraíra e o tranquilizava no começo. E agora: que fútil, que enfatuado, que torpe! Porque agora ele media com medidas cósmicas, pelas quais se sentia sacudido e agitado. Que confiança um no outro? Que perigo? E que abismo entre as pessoas! Consolação! Consolação?... Acaso existe consolação? (KEILSON 2011:58)

Portanto, a perspectiva da narração recai, em diversas passagens, sobre a personagem do judeu oculto, revelando a angústia do claustro, suas inquietações e questionamentos. A sensação de iminente ameaça, por vezes, é desproporcional à tranquilidade que efetivamente se observa no ambiente; a gravidade dos pensamentos de Nico, portanto, favorecem uma percepção empática do leitor diante do fato histórico e social que é revelado através dessa personagem. Constitui-se assim a narrativa de perspectivas múltiplas, como explica Hartner (2019: s/p): “multiperspectivismo é um aspecto básico da narração, ou um modo de narrar no qual pontos de vista múltiplos - e frequentemente discrepantes - são empregados para a apresentação e julgamento da

\footnotetext{
9 'the way of representation of the story is influenced by the position, personality and values of the narrator, the characters and, possibly, other more hypothetical entities in the storyworld“"

Pandaemonium, São Paulo, v. 23, n. 41, set.-dez. 2020, p. 176-190
} 
ANDRADE, P.H.B. - Empatia e conflito entre o trágico e o cômico

história e do mundo da ficção" ${ }^{10}$. O conceito, que abrange também narrativas com vários narradores, trata do mesmo modo de textos com focalizações múltiplas, com a orquestração de múltiplas vozes e suas respectivas posições ideológicas. Se a obra de Keilson tem valor documental, como afirma Niekerk (2013: 116) pouco acima mencionado, podemos asseverar que o período histórico é documentado entretecendo as visões dos diferentes estratos sociais envolvidos. Desta forma, o autor retrata uma Holanda sob domínio nazista com todas as consequências de tal conformação: desde as menores, como a falta de carne para colocar na sopa que aborrecia a sistemática dona de casa Marie, até as mais contundentes e fatais, como a necessidade de se enclausurar como única esperança de sobrevivência para os judeus.

Não estão à parte, dessa forma, as implicações éticas de tal escrita. De acordo com Zunshine (apud GALLE 2018: 32, a ficção possibilita ao leitor compreender raciocínios, percepções, sentimentos e intenções de outra pessoa. Saber como é vivenciar algo que um outro experimentou suscita o que Keen (2019) chama de empatia narrativa. A autora discorda da conhecida postulação “willing suspension of disbelief” [suspensão intencional da descrença], de Coleridge, e ratifica a afirmação de Gerrig, de que o leitor precisa, antes, de um esforço para não acreditar no que lê. Embora a evocação de emoções reais por narrativas ficcionais seja um tópico controverso, a autora reafirma a implicação ética de uma narrativa potencialmente empática:

A situação de um leitor individual com respeito à criação estratégica de empatia pelo autor depende, em parte, de aspectos de identidade e narração. Quando as atitudes dos leitores se alteram, ou quando são encorajados tácita ou explicitamente a realizar ações altruístas a favor de outros que são representados por quem sentem empatia narrativa, o impacto pode ser considerado um aspecto ético no discurso da narrativa. ${ }^{11}$ (KEEN 2019: $\mathrm{s} / \mathrm{p})$.

A questão da recepção e da empatia do leitor é especialmente relevante para a literatura do e sobre o período nacional-socialista da história europeia. Se analisarmos obras de autores politicamente engajados como Anna Seghers, Klaus Mann ou Bertolt Brecht, veremos que a ideia de um Volksfront (frente popular) - difundida pelos periódicos publicados no exílio - aparece nas obras da época como figuração literária de

\footnotetext{
10 "multiperspectivity [is] a basic aspect of narration or a mode of storytelling in which multiple and often discrepant viewpoints are employed for the presentation and evaluation of a story and its storyworld"

11 "The situation of an individual reader with respect to author's strategic empathizing depends in part on aspects of identity and narration. When readers' attitudes alter, or when they receive tacit or explicit encouragement to undertake altruistic action on behalf of represented others for whom they feel narrative empathy, the impact can be considered an aspect of ethics in narrative discourse".
} 
ANDRADE, P.H.B. - Empatia e conflito entre o trágico e o cômico

atitudes de resistência, transgressoras às normas do Reich e solidárias para com os perseguidos (ANDRADE 2015). De acordo com tal conceito, caberia aos cidadãos comuns a tarefa de exercer resistência ao fascismo, atuando em suas esferas e entretecendo uma rede de colaboração entre os perseguidos e aqueles que se dispunham a ajudá-los. Em Comédia em tom menor, tal construção de personagens acaba por suscitar mais um elemento cômico, que é a mediocridade de Wim e Marie, jovem casal sem grandes atributos heroicos, que se preocupava com detalhes cotidianos - como as provas para a promoção na empresa, ou o fornecimento de alimentos; ainda assim, essas pessoas comuns tiveram coragem o bastante para arriscar-se em prol de uma vítima do antissemitismo nazista. Sua mediocridade, portanto, antes de diminuí-los, torna-os mais próximos do homem comum e do leitor, afirmando que qualquer pessoa poderia - ou deveria - engajar-se em ações humanitárias e de resistência ao nazismo.

Não apenas pelos trechos com focalização em Nico a empatia narrativa é gerada. Vemos, por exemplo, na passagem abaixo transcrita a empatia da personagem Marie por Nico quando ela, após a morte do hóspede, arruma seu quarto e encontra escondido um maço de cigarros Lucky Star, bastante raros à época e que, segundo Marie, teriam sido muito apreciados por Wim se Nico os tivesse compartilhado.

E de repente Marie compreendeu, compreendeu perfeitamente. Viu-o ali à sua frente. Sentiu um nó e um aperto na garganta, que ficou seca, e, sem que ela soubesse, seus olhos se encheram de lágrimas. Marie sentou-se no divã, o maço de cigarros ainda na mão. Ele fumava sozinho! Fumava quando estava a sós - quando a solidão o devastava -, quando não aguentava mais... Escondido! (KEILSON 2011: 83)

Em um primeiro momento, ao encontrar o maço de cigarros, Marie não compreendeu porque Nico não o dividira com Wim, sabendo que ele se arriscava e dividia seu próprio teto e alimento com o estranho. Em um primeiro momento, Marie chega a considerar como egoísta a atitude de Nico de guardar os "preciosos" cigarros só para si. No excerto acima citado, a jovem mulher tem uma revelação - ou percepção mais empática - de que o judeu os guardava como um último marco de individualidade em sua vida devastada, para breves momentos de alívio nas piores horas de angústia e depressão. A focalização interna em Marie, desta forma, opera uma aproximação da subjetividade, ou uma leitura mais empática dos sofrimentos do judeu perseguido.

De acordo com Mar e Oatley (2008: 185), “[...] é este realismo psicológico, não as características superficiais da configuração da narrativa, que determina se podemos 
ANDRADE, P.H.B. - Empatia e conflito entre o trágico e o cômico

adquirir informações sociais e processos úteis de uma obra de ficção". ${ }^{12}$ Para os autores, obras ficcionais são capazes de criar uma experiência simulativa profunda e imersiva de interações sociais para os leitores (173): "tomar o ponto de vista de outra pessoa reduz os estereótipos e o favoritismo de grupo" 13 (181). Eles recorrem a pesquisas anteriormente publicadas para argumentar: "Pesquisas recentes mostraram que indivíduos que foram expostos a mais literatura ficcional tendem a demonstrar mais habilidades empáticas"14 (MAR; OATLEY 2008: 181).

Tal argumento é também defendido por Djikic et al (2009), cujo artigo relata uma experiência feita com dois grupos de leitores pertencentes a um ambiente universitário: enquanto um grupo leu um conto de Tchekov, o outro leu um texto de caráter documental com conteúdo comparável ao do conto. Os autores observaram, ao submeter questionários antes e depois da leitura aos dois grupos, que "a leitura de narrativas ficcionais mostrou envolver processos de identificação e 'autoimplicação', e modificar o leitor” (DJIKIC et al. 2009: 25). A conclusão dos pesquisadores a partir dos resultados dos questionários é que a arte pode implicar um "processo de transformação através de mudanças emocionais" (DJIKIC et al. 2009: 28); portanto, ao evocar a empatia do leitor através da focalização ou outros expedientes para identificação, a obra ficcional contribui para a formação ética do leitor.

A partir do capítulo 11, altera-se a situação do casal, em iminente perigo, e desloca-se a narrativa do espaço que até então predominava - o da casa. Esta, que é cenário da maior parte das cenas do conto, tem suas fronteiras cruzadas em quatro momentos principais (WIDMANN 2013: 63): a chegada de Nico, a saída de seu corpo após a morte, a saída do casal por alguns dias, para evitar uma possível prisão caso fossem identificados como benfeitores do homem, e seu retorno para casa. Esta só foi possível graças à articulação da cunhada Coba, que, surpreendentemente, também auxiliava fugitivos encontrando-lhes esconderijos, e que obteve contatos junto às autoridades para se certificar de que Wim e Marie não teriam problemas.

\footnotetext{
12 " [...] it is this psychological realism, not the superficial characteristics of the setting, that determines whether we can learn useful social information and processes from a work of fiction".

13 "taking the perspective of another person reduces stereotyping and ingroup favouritism".

14 "[Researches] have recently shown [...] that individuals who have been exposed to more fictional literature tend to exhibit better emphatic abilities".
}

Pandaemonium, São Paulo, v. 23, n. 41, set.-dez. 2020, p. 176-190 


\section{Considerações finais}

Ao passo que o jovem casal Wenders foi convidado por um conhecido a abrir suas portas para Nico, a descoberta da atuação da cunhada surpreende Marie e sugere, aliada à naturalidade com que o doutor Nelis atende o doente e compreende sua situação, que uma vasta rede oculta para auxílio dos perseguidos se formara na sociedade holandesa durante o período de dominação nazista. Sabendo-se que não foram raros os casos de ocultação de refugiados por parte dos holandeses, o romance ficcional de Keilson mantém suas bases na realidade histórica da invasão da Holanda pela Alemanha durante a Segunda Guerra Mundial. Havendo vivenciado tal situação enquanto exilado, o escritor escolheu a ficção como forma de aproximar do leitor a experiência da perseguição e do medo, com a vantagem de poder fazê-lo através de múltiplas perspectivas.

A empatia aparece no romance em vários níveis: no textual, através da perspectiva - principalmente de Marie e Wim após a morte de Nico e sua própria experiência como fugitivos; nas atitudes de personagens secundárias como Coba, o doutor Nelis e a conivente faxineira; e ainda no leitor, se considerarmos as implicações éticas da perspectiva que revela a agonia de Nico em seu claustro necessário à sobrevivência. Ainda que se constitua como obra ficcional, a leitura de Comédia em tom menor permite ao leitor uma "experiência simulativa" (MAR; OATLEY 2008: 173) tão eficiente quanto qualquer outra forma de denúncia da violência imposta pelo nazismo.

Portanto, atua no nível do leitor a evocação de um conhecimento comum - sobre a triste realidade histórica retratada - para a constituição do cômico na narrativa, ainda que este posteriormente se dissolva com a prevalência do tom trágico em várias passagens do romance. Assevera-se a afirmação de Walton (2018: 286) de que "as obras [literárias] talvez sirvam menos como veículos para argumentos 'factuais' e mais para argumentos morais": expondo as dores de personagens representativas de outros tantos sujeitos reais, a obra de Keilson suscita empatia e contribui para o desenvolvimento moral do leitor.

\section{Referências bibliográficas}

ANDRADE, P. H. B. Vozes do desterro: a Literatura de Exílio alemã em seus periódicos e na obra de Anna Seghers. Tese (Doutorado) - Universidade Estadual Paulista Júlio de Mesquita Filho, Faculdade de Ciências e Letras (Campus de Araraquara), 2015. 
BERGSON, H. O riso. Ensaio sobre a significação da comicidade. Trad. Ivone Castilho Benedetti. São Paulo: Martins Fontes, 2004, p. 98-145.

BRAESE, S. Dissidente Zeugenschaft: Hans Keilson's Der Tod des Widersachers im Kontext der deutschsprachigen Nachkriegsliteratur. In: VogEL-KLEIN, R. (org.). Die ersten Stimmen: deutschsprachige Texte zur Shoah 1945-1963. Würzburg: Königshausen \& Neumann, 2010, p. 33-48.

DJIKIC, M. et al. On being moved by art: how reading fiction transforms the self. Creativity Research Journal, v. 2, n. 1, p. 24-29, 2009.

DÜRRENMATT, F. Theaterprobleme [1955]. In: DÜRRENMATT, F. Theater. Essays, Gedichte und Reden. Zürich: Diogenes, 1985, p. 31-72.

FLAMSON, T.; BARRETT, H.C. The encryption theory of humor: a knowledge-based mechanism of honest signaling. Journal of Evolutionary Psychology, v. 6, n. 4, p. 261-281, 2008.

GALlE, H. Pequena introdução à teoria da ficcionalidade seguida por uma bibliografia. In: GALLE, H.P.E., PEREZ, J.P., PEREIRA, V.S. (orgs.). Ficcionalidade: uma prática cultural e seus contextos. São Paulo: FFLCH/USP, 2018, p.17-43.

GENETTE, G. Discurso da narrativa. Lisboa: Vega, 1995.

HARTNER, M. Multiperspectivity. In: HÜHN, P. et al. (orgs.). The living handbook of narratology. Hamburg: Hamburg University. Disponível em: http://www.lhn.unihamburg.de/article/multiperspectivity. Acesso em: 18 jul. 2019.

KEEN, S. Narrative empathy. In: HÜHN, P. et al. (orgs.). The living handbook of narratology. Hamburg: Hamburg University. Disponível em: http://www.lhn.unihamburg.de/article/narrative-empathy. Acesso em: 18 jul. 2019.

KeILson, Hans. Comédia em tom menor. Tradução de Luiz A. de Araújo. São Paulo: Companhia das Letras, 2011.

MAR, R.; OATLEY, K. The function of fiction is the abstraction and simulation of social experience. Perspectives on Psychological Science, n. 2, p.173-185, 2008.

Niederhoff, B. Perspective - Point of View. In: HüHn, P. et al. (orgs.). The living handbook of narratology. Hamburg: Hamburg University. Disponível em: http://www.lhn.unihamburg.de/node/26.html. Acesso em: 18 jul. 2019.

NIEKERK, C. Hans Keilson im Exil. Zur jüdisch-niederländisch-deutschen Transkulturation. In: SCHRÖDER, S.;WEYMANN, U.; WIDMANN, A. (orgs.). "Die vergangene Zeit bleibt die erlittene Zeit”: Untersuchungen zum Werk von Hans Keilson. Würzburg: Königshausen \& Neumann, 2013, p. 105-126.

Walton, K. Moral na ficção e moralidade ficcional. In: Galle, H.P.E., Perez, Juliana P., PEREIRA, Valéria S. (orgs). Ficcionalidade: uma prática cultural e seus contextos. São Paulo: FFLCH/USP, 2018, p. 283-306.

WEYMANN, U. Erinnerung und Wirklichkeitsverlust in „Der Tod des Widersachers“. In: SCHRÖDER, S.;WEYMANN, U.; WIDMANN, A. (orgs.). "Die vergangene Zeit bleibt die erlittene Zeit”: Untersuchungen zum Werk von Hans Keilson. Würzburg: Königshausen \& Neumann, 2013, p. 71-89.

WidMAnN, Andreas Martin. „In der Kammer“. Erzählform und Motivstruktur in Komödie in Moll. In: SCHRÖDER, S.; WeYMANN, U.; WIDMANN, A. (orgs.). "Die vergangene Zeit bleibt die erlittene Zeit": Untersuchungen zum Werk von Hans Keilson. Würzburg: Königshausen \& Neumann, 2013, p. 53-70. 